\title{
Uzaktan Eğitim Sürecinde Öğretmenlerin Örgütsel Muhalefet ve Örgütsel Yalnızlık Algı Düzeylerinin İncelenmesi
}

\author{
Ümit DOĞAN \\ Sakarya İl Milli Eğitim Müdürlüğü \\ doganumit18@hotmail.com \\ ORCID ID: 0000-0002-8144-9744 \\ Seyfettin ABDURREZZAK \\ Edirne İl Milli Eğitim Müdürlüğü \\ srezzak@ hotmail.com \\ ORCID ID: 0000-0001-9892-7506 \\ Yalçın Varol YILDIZBAŞ \\ Van İl Milli Eğitim Müdürlüğü \\ yalcinvarol@hotmail.com \\ ORCID ID: 0000-0002-9134-4276 \\ Ramazan ÖZKUL \\ Malatya İl Milli Eğitim Müdürlüğü \\ ramazanozkul4427@gmail.com \\ ORCID ID: 0000-0001-9757-6062
}

Araştırma Makalesi

DOI: $10.31592 /$ aeusbed.978062

Geliş Tarihi: 03.08.2021

Revize Tarihi: 22.11.2021

Kabul Tarihi: 28.11.2021

\section{Atıf Bilgisi}

Doğan, Ü., Abdurrezzak, A., Yıldızbaş, S. ve Özkul, R. (2021). Uzaktan eğitim sürecinde öğretmenlerin örgütsel muhalefet ve örgütsel yalnızlık algı düzeylerinin incelenmesi. Ahi Evran Üniversitesi Sosyal Bilimler Enstitüsü Dergisi, 7(3), 1086-1099.

\section{ÖZ}

$\mathrm{Bu}$ araştırma uzaktan eğitim sürecinde öğretmenlerin örgütsel muhalefet ve örgütsel yalnızlık algı düzeylerini belirlemek amacıyla gerçekleştirilmiştir. Öğretmenlerin görüşlerinin cinsiyet, mezun olunan fakülte, öğrenim durumu, branş, yaş ve mesleki kıdem değişkenleri açısından anlamlı farklılık gösterip göstermediği belirlenmeye çalışılmıştır. Bu kapsamda araştırma modeli olarak genel tarama modeli tercih edilmiştir. Araştırmanın evrenini Sakarya ilinde görev yapan öğretmenler oluşturmaktadır. Araştırmanın örneklemi tesadüfi olmayan örnekleme yöntemlerinden kolayda örnekleme yöntemi kullanılarak toplam 192 öğretmen oluşturmaktadır. Veri toplamak için Örgütsel Muhalefet Ölçeği ve İş Yaşamında Yalnızlık Ölçeği kullanılmıştır. Toplanan veriler üzerinden betimsel istatistikler yapılmıştır. Yapılan araştırma neticesinde; uzaktan eğitim sürecinde öğretmenlerin örgütsel muhalefet algıları cinsiyet ve mezun olunan fakülte değişkenlerine göre anlamlı farklılık göstermezken, mezuniyet durumu değişkenine göre anlamlı farklılık gösterdiği, lisansüstü mezunu öğretmenlerin örgütsel muhalefet algılarının lisans mezunu öğretmenlere göre daha düşük düzeyde olduğu tespit edilmiştir. Öğretmenlerin örgütsel yalnızlık algılarının cinsiyet, mezuniyet durumu, mezun olunan fakülte, branş ve mesleki kıdem değişkenlerine göre anlamlı farklılık göstermediği, öğretmenlerin örgütsel muhalefet algıları ile örgütsel yalnızlı algıları arasında pozitif yönde ve orta düzeyde bir ilişki olduğu, örgütsel muhalefetin örgütsel yalnızlığın anlamlı bir yordayıcısı olduğu saptanmıştır. Araştırma neticesinde öğretmenlerin örgütsel muhalefet davranışlarının ve örgütsel yalnızlık sebeplerinin özellikle uzaktan eğitim sürecinde daha iyi anlaşılması açısından nitel araştırmalarla desteklenmesinin önemi vurgulanmıştır.

Anahtar Kelimeler: Uzaktan eğitim, örgütsel muhalefet, örgütsel yalnızlık.

\section{Investigation of Organizational Dissent and Organizational Loneliness Perception Levels of Teachers in Distance Education Process}

\begin{abstract}
This study was applied to determine the organizational dissent and organizational loneliness perception levels of teachers in the distance education process. It was tried to determine whether the opinions of the teachers differed significantly in terms of gender, faculty graduated, educational status, branch, age and professional seniority. In this context, the general survey model was preferred as the research model. The universe of the research consists of teachers working in Sakarya province. The sample of this study consists of 192 teachers who use the convenience sampling method, one of the non-random sampling methods. Organizational Dissent Scale and Loneliness at Work Scale were used to collect data. Descriptive statistics were made on the collected data. As a result of the research; While teachers' perceptions of organizational dissent in the distance
\end{abstract}


education process did not differ significantly according to gender and graduated faculty variables, it was determined that there was a significant difference according to the graduation status variable, and it has been determined that the organizational opposition perceptions of the graduate teachers are lower than those of the undergraduate graduates. It was determined that teachers' perceptions of organizational loneliness did not differ significantly according to gender, graduation status, graduated faculty, branch and professional seniority, there was a positive and moderate relationship between teachers' perceptions of organizational dissent and organizational loneliness, and organizational dissent was a significant predictor of organizational loneliness. In this research, it was emphasized that the importance of supporting teachers with qualitative studies in terms of better understanding the organizational dissent behaviors and the reasons for organizational loneliness, especially in the distance education process.

Keywords: Distance education, organizational dissent, organizational loneliness.

\section{Giriş}

Eğitim örgütlerinde önemli görevleri bulanan öğretmenlerin, diğer örgüt çalışanlarından farklı olarak daha fazla aidiyet ve sevgi ihtiyac1 duydukları ve bu ihtiyacı bulundukları ortamdan karşıladıklarını söylemek mümkündür (Nartgün ve Demirer, 2012).Okullardaki beklentiler toplumun gereksinimlerinin artması ile birlikte daha üst düzeye ulaştı̆̆ı ifade edilmiştir (Şahin ve Atbaşı, 2020). Öğretmenlerin bulundukları ortamdan beklentilerinin yanı sıra diğer paydaşların öğretmenlerden beklentileri büyük bir stres faktörü olarak dikkat çekmektedir. Öğretmenlerin yaşanan stres sonrasında muhalefet gösterme ya da yalnızlık duygusuyla karşılaşmaları mümkündür. Karaduman'a (2013) göre yaşanan olumsuz duygular, öğretmenlerin motivasyonlarını azaltacak, iş doyumunu olumsuz etkileyecek ve diğer paydaşlarla iletişimlerinin zayıflamasına neden olacaktır.

Muhalefet, Latince ayr1 anlamına gelen "dis" ve hissetmek anlamına gelen "sentire" kelimelerinden türetilen ayrı hislerde olmak anlamındaki "dissentire" kelimesidir (Kassing, 2007). Arapça $h-l-f$ kökünden oluşan farklı yolları, görüşleri seçmek, ihtilaf etmek anlamına gelen bir kavramdır (Ardoğan, 2004).

Örgütsel muhalefet ise, örgüt çalışanlarının örgütte karşılaştıkları uygulamalara karşı çalışanlar ya da yöneticilerle uyuşmazlık yaşamaları, ortaya çıkan sorunları farklı davranışlarla göstermelerini içerir (Redding, 1985). Çalışanlar tarafından ortaya konan davranışlar, örgütte karşılaşılan davranışlar, içinde bulunulan durum ve yaşanan olaylara dayalı olarak ortaya çıkmaktadır (Kassing ve Armstrong, 2002). Kassing'e (2008) göre örgütlerde ortaya çıkan muhalif davranışlar üç şekilde ortaya çıkabilir:

- Dikey ya da açık muhalefet, örgütte ortaya çıkan sorunların yönetim kademesinde bulunanlara doğrudan açık ve anlaşılır bir biçimde ifade edilmesidir.

- Yatay ya da gizli muhalefet, bireyin örgütte ortaya çıkan olumsuzlukları, yöneticilere iletmeden kendisiyle aynı düzeyde olan çalışanlarla paylaşmasıdır.

- Dışsal ya da yer değiştirmiş muhalefette ise, çalışanlar örgütlerde yaşadıkları olumsuzlukları örgüt dışında kalan yabancılara, arkadaşlarına ve aile üyelerine anlatmalarını içerir.

Yalnızlık, "yalnız olma durumu, kimsesizlik, kimse bulunmama durumu, 1ssızlık, tenhalık" anlamlarına gelmektedir (Türk Dil Kurumu, 2021). "Yalnızlık, insanların başkalarıyla iletişim kurmada zorlanması sonrasinda meydana gelen memnun olmama durumu veya ruhsal olarak sikınt1 yaşamasıdır" (Güney, 2004, s.260). Bireyler iletişim kurmada zorlanınca, psikososyal olarak yetersizlik duyacak, diğer insanlardan uzaklaşacak ve kendini soyutlama yoluna gidecektir (Yakut ve Certel, 2016).

Yalnızlık yaşayan bireyler, çevreleriyle iletişim kurmakta zorlandıkları gibi kaygılı bir yapıya bürünürler (Sergin ve Kinley, 2005). Bireylerin ilişkilerinde karşı tarafa güven duymamaları, olumsuz olaylarla karşılaşmaları, iyi arkadaş edinememelerine ve dolayısıyla ruhsal olarak çökmelerine neden olmaktadır (Kaplan, 2011). Gafa ve Dikmenli (2019) araştırmasında öğretmenlerin iş yaşamlarında kendilerini yalnız hissetmelerininaile, sosyal çevre ve öğrencileri üzerinde de bir takım olumsuz etkileri olabileceğini belirtmiştir. 
Örgütsel yalnızlık ise bireyin özel hayatındaki yalnızlık durumundan farklı olarak iş hayatında ortaya çıkan, ilişkilerinin iyi olmaması ve arkadaşlık kurmada zorlanma sonucunda yaşanan durumdur (Kayaalp ve Özdemir, 2020). Örgütte diğer çalışanlarla ilişkilerin zayıflaması, güven duygusunun zedelenmesi sonucunda birlikte geçirilen zamanın azalması örgütsel yalnızlı̆̆a neden olmaktadır (Mercan, Oyur, Alamur, Gül ve Bengül, 2012).

Örgütte bulunanlar tarafından kabul görmeme, istenmeme sonucunda bazı çalışanlar yalnızlık duygusuna kapılabilirler (Wright, Burt ve Strongman, 2006). Bireyler, çalıştıkları örgütte bireysel, çevresel ve örgütsel etmenlerden dolayı yalnızlık yaşayabilirler. Örgütsel yalnızlığa neden olan etmenleri, ailenin desteği, yaşanılan kültürün yapısı, örgüt iklimi, örgütteki iletişim, örgüt çalışanlarının ve yöneticilerinin desteği, yapılan işin yükü, alınan sorumluluklar ve sıkılma şeklinde siralamak mümkündür (Wright, 2005).

Örgütsel yalnızlık, bireylerin arkadaşlarıyla birliktelik kuramaması ve kendini örgütün bir parçası olarak görememesi sonucu gelişen sosyal arkadaşlık yalnızlı̆̆ ile iş arkadaşlarına karşı tavır göstermesi, görüşlerini dile getirmemesi, paylaşımda bulunmaktan kaçınması sonucu ortaya çıkan duygusal yoksunluk şeklinde görülebilir (Doğan, Çetin ve Sungur, 2009).

Bu araştırmanın amacı, uzaktan eğitim sürecinde öğretmenlerin örgütsel muhalefet ve örgütsel yalnızlık algı düzeylerinin incelenmesidir. $\mathrm{Bu}$ amaç, aşağıda belirtilen sorular bağlamında incelenecektir:

1. Öğretmenlerin örgütsel muhalefet ve örgütsel yalnızlık algıları ne düzeydedir?

2. Öğretmenlerin örgütsel muhalefet ve örgütsel yalnızlık algıları cinsiyet, mezun olunan fakülte, öğrenim durumu, branş, yaş ve mesleki kıdem değişkenlerine göre anlamlı bir farkl111k göstermekte midir?

3. Öğretmenlerin örgütsel muhalefet algıları, örgütsel yalnızlık algılarının anlamlı bir yordayıc1sı midır?

Uzaktan eğitim sürecinin uygulanmasıyla, bu süreci iyi yönetmeye çalışan öğretmenlerin, örgütsel muhalefet ve örgütsel yalnızlık algı düzeylerinin incelenmesi önemli görülmektedir. Yapılan alan yazın taramasında, eğitim örgütlerinde öğretmenlerin örgütsel muhalefet ve örgütsel muhalefet algı düzeyleri arasındaki ilişkiyi inceleyen herhangi bir araştırmaya rastlanmamıştır. $\mathrm{Bu}$ durum, araştırmanın özgünlüğ̈̈nü ortaya koymaktadır.

\section{Yöntem}

Araştırmanın yöntem kısmında, araştırma modeli ile evren ve örneklem başlıklarına yer verilmiştir. Veri toplama araçları ve verilerin analizi başlıklarında kullanılan ölçekler ve yapılan analizler ifade edilmiştir. Ayrıca araştırma etiği başlığında etik kurul izni ile bilgilere yer verilmiştir.

\section{Araştırma Modeli}

$\mathrm{Bu}$ araştırmada, öğretmenlerin örgütsel muhalefet ve örgütsel yalnızlık algısı için nicel araștırma desenlerinden tarama modeli tercih edilmiștir. Tarama modeli, geçmiş veya mevcut durumu betimlemek için tasarlanmış bir araştırma yöntemidir. Bu model, evren hakkında genel yargılarda bulunabilmek için tüm evreni veya ondan alınan örnekleri tarar (Karasar, 2010). İlişkisel tarama modeli ile öğretmenlerin algılanan örgütsel muhalefet ile örgütsel yalnızlık düzeyi arasındaki ilişki belirlenmiştir. İlişkisel tarama modelleri, iki veya daha fazla değişken arasındaki değişimin varlığını ve derecesini belirlemek ve nedensellik hakkında ipuçları elde etmek için kullanılmaktadır (Büyüköztürk, Çakmak, Akgün, Karadeniz ve Demirel, 2008; Karasar, 2010). 


\section{Evren ve Örneklem}

Araştırma evreni 2020-2021 eğitim ve öğretim y1lında Sakarya ilinde görev yapan 13422 öğretmen oluşturmaktadır. Araştırma kapsamında tüm öğretmenlere ulaşmanın zor olduğu düşünüldüğünden örneklem seçilmiştir. Örneklem, tesadüfi olmayan örnekleme yöntemlerinden kolayda örnekleme yöntemi kullanılarak oluşturulmuştur. Kolay örneklemede veriler, evrenden en hızlı ve ekonomik şekilde toplanır (Malhotra, 2004; Zikmund, 2007). Bu kapsamda araştırmanın örneklemini 192 öğretmen oluşturmaktadır. Örneklemdeki öğretmenlerin bazı demografik bilgileri Tablo 1'de gösterilmiştir.

Tablo 1

Katılımclların Demografik Özellikleri

\begin{tabular}{llll}
\hline Değişken & Gruplar & $\mathbf{n}$ & \% \\
\hline \multirow{2}{*}{ Cinsiyet } & Kadın & 116 & 60.42 \\
& Erkek & 76 & 39.68 \\
Mezun Olunan Fakülte & Eğitim & 163 & 85.42 \\
& Diğer & 29 & 14.68 \\
Öğrenim Durumu & Lisans & 166 & 88.64 \\
& Lisansüstü & 26 & 11.46 \\
Branş & Okul Öncesi & 33 & 17.29 \\
& Sinıf & 47 & 24.48 \\
& Branş & 112 & 58.33 \\
Yaş & 30 yaş ve altı & 100 & 51.92 \\
& $31-40$ yaş & 60 & 31.35 \\
& $41-50$ yaş & 15 & 8.17 \\
Kidem & 51 yaş ve üstü & 17 & 8.95 \\
& $0-5$ yil & 87 & 46.19 \\
Toplam & 6-10 yil & 61 & 31.61 \\
\hline
\end{tabular}

Tablo 1'e göre öğretmenlerin 116's1 (\%60.42) kadın, 76's1 (\%39.68) erkektir. Öğretmenlerin 163'ü (\%85.42) eğitim fakültesi mezunu iken, 29'u (\%14.68) diğer fakültelerden mezundur. Katılımcıların 166's1 (\%88.64) lisans, 26’s1 (\%11.46) ise lisansüstü mezunudur. Öğretmenlerin 33’ü (\%17.29) okul öncesi, 47'si (\%24.49) sınıf, 112'si (\%58.38) ise branş öğretmenidir. Araştırmaya katılan öğretmenlerin 100'ü (\%51.92) 30 yaş ve altında, 60’1 (\%31.35) 31-40 yaş, 15’i (\%8.17) 41-50 yaş, 17'si (\%8.95) 51 yaş ve üstündedir. Öğretmenlerin kıdemleri incelendiğinde ise 88 'i (\%46.19) $0-5$ y1l, 61'i (\%31.61) 6-10 yıl, 27'si (\%13.64) 11-19 y1l, 17’si ise (\%8.95) 20 yıl ve üstü k1deme sahiptir.

\section{Veri Toplama Araçları}

Araştırmada, öğretmenlerin örgütsel muhalefet algılarını ölçmek amacıyla ''Örgütsel Muhalefet Ölçeği', iş yaşamında yalnızlık algılarını ölçmek için 'İş Yaşamında Yalnızlık Ölçeği',, katılımcıların demografik bilgilerini edinmek amacıyla araştırmacılar tarafından geliştirilen demografik bilgiler formu kullanılmıştır.

Örgütsel Muhalefet Ölçeği: Örgütsel muhalefet ölçeği Kassing (2008) tarafindan geliştirilmiştir. Dağlı (2015) ise araştırmasında ölçeğin Türkçe uyarlamasiile geçerlik ve güvenilirlik çalışmasını yapmıştır. Örgütsel Muhalefet Ölçeği yapılan uyarlama çalışması sonucunda toplam 15 madde ve iki alt boyut olarak belirlenmiştir. Dağlı (2015) ölçeğin güvenirliği açısından gerek boyut gerekse ölçeğin geneli için iç tutarlılık katsayılarını: Dikey Muhalefet “.79”, Yatay Muhalefet ".82" ve Ölçeğin Geneli için ".85" hesaplanmıştır. Bu araştırmada belirlenen iç tutarlık katsayı değerleri ise; Dikey Muhalefet “.80”, Yatay Muhalefet “.81” ve Ölçeğin Geneli için “.83” olarak hesaplanmıştır. 
ISs Yaşamında Yalnızlık Ölçeği: Wright, Burt ve Strongman (2006) tarafından geliştirilen iş yaşamında yalnızlık ölçeğinin Türkçeye uyarlama ve geçerlik ve güvenilirlik çalışmasını Doğan, Çetin ve Sungur (2009) yapmıştır. İş Yaşamında Yalnızlık Ölçeğinin toplam 16 madde ve iki alt boyuttan oluşmaktadır. Doğan, Çetin ve Sungur(2009) ölçeğin güvenirliği açısından gerek boyut gerekse ölçeğin geneli için iç tutarlılık katsayılarını: Duygusal Yoksunluk Boyutu ".87”, Sosyal Arkadaşlık Boyutu ".83" ve Ölçeğin Geneli için ".91" hesaplanmıştır. Bu araştırmada ise iç tutarlık katsayıları; Duygusal Yoksunluk Boyutu ".88”, Sosyal Arkadaşlık Boyutu ".87” ve Ölçeğin Geneli için ".93” olarak belirlenmiştir.

\section{Verilerin Analizi}

$\mathrm{Bu}$ araştırmanın bağımsız değişkenleri için gerekli olan betimsel istatistikler belirtilmiştir. Analizlerde, öğretmenlerin örgütsel muhalefet ve örgütsel yalnızlık alg1 düzeyleri cinsiyet, medeni durum ve öğrenim durumu değiş̧kenlerine göre anlamlı farkların belirlenmesinde bağımsız gruplar için t-testi, kıdem değişkenine göre anlamlı fark olup olmadığının belirlenmesinde Tek Yönlü Varyans Analizi uygulanmıştır. Gruplar arası farklılı̆̆ın belirlenmesinde scheffe testi yapılmıştır. Öğretmenlerin örgütsel muhalefet ve örgütsel yalnızlık alg1 düzeyleri arasındaki ilişkinin belirlenmesinde Pearson's Korelasyon analizi yapılırken öğretmenlerin örgütsel muhalefet algılarının örgütsel yalnızlık algılarını yordama derecesini ortaya çıkarmak amacıyla regresyon testi yapılmıştır.

Beşli ölçeğin değer farkının (5-1), değer yargısına (5) bölünmesi ile elde edilen .80’lik aralıklar maddelerin benimsenme düzeyinin sınırlarını belirlemektedir. Aritmetik ortalamaların yorumlanmasında 1.00-1.80 "Çok Düşük", 1.81-2.60 "Düşük", 2.61-3.40 “Orta", 3.41-4.20 "Yüksek" ve 4.21-5.00 "Çok Yüksek" aralıkları ve düzeyleri kullanılırken; değişkenler arasındaki ilişkinin düzeyini belirlemek amacıyla .00-.29 "Düşük", .30-.69 "Orta" ve .70-1.00 "Yüksek" aralık değerleri ve düzeyleri kullanılmıştır.

Araştırmanın veri analiz bölümünde ilk etapta ölçek sorularına verilen yanıtların frekans ve yüzdelik dağılımları bulunmuştur. Daha sonra verilerin normal dağılım gösterip göstermedikleri incelenmiştir. Normallik testi için Skewness ve Kurtosis değerlerine bakılmıştır. Skewness değeri .175 bulurken Kurtosis değeri ise -.845 olmuştur. Kurtosis ve Skewness değerleri -1.5 ile +1.5 olduğu zaman normal dağılım olduğu kabul edilmektedir.Bu nedenle ölçeğin toplam puanlarının normal dağılım gösterdiği anlaşılmıştır (Büyüköztürk, vd., 2008).

\section{Araştırma Etiği}

Araştırma verilerinin toplanma sürecinden önce İnönü Üniveristesi Sosyal ve Beşeri Bilimler Bilimsel Araştırma Etik Kurulu' nun 05/07/2021 tarihli E.61621 sayılı kararı ile etik kurul izni alınmıştır. Araştırmanın etik açıdan uygun olduğu kararından sonra araştırma sürecine başlanmıştır.

\section{Bulgular}

Araştırmada öğretmenlerin örgütsel muhalefet ve örgütsel yalnızlık algıları arasındaki ilişki cinsiyet, yaş, branş, mezuniyet, mezun olunan fakülte ve mesleki kıdem değişkenleri temelinde ortaya konulmuştur.

\section{Öğretmenlerin Örgütsel Muhalefet ve Örgütsel Yalnızlık Algılarının Düzeyine Yönelik Bulgular}

Araştırmada ilk olarak öğretmenlerin örgütsel muhalefet ve örgütsel yalnızlık algılarının düzeyleri boyutlar da göz önüne alınarak incelenmiş ve Tablo 2'de elde edilmiş olan bulgulara yer verilmiştir. 
Tablo 2

Öğretmenlerin Örgütsel Muhalefet ve Örgütsel Yalnızlık Algılarının Düzeyine İlişkin Bulgular

\begin{tabular}{lccc}
\hline Ölçek ve Boyutları & $\mathbf{n}$ & $\overline{\mathbf{X}}$ & $\mathbf{S}$ \\
\hline Örgütsel Muhalefet & 192 & 2.64 & 0.39 \\
Dikey Muhalefet & 192 & 2.84 & 0.47 \\
Yatay Muhalefet & 192 & 2.12 & 0.48 \\
Örgütsel Yalnızlık & 192 & 3.49 & 0.30 \\
Duygusal Yoksunluk & 192 & 3.33 & 0.37 \\
Sosyal Arkadaşlık & 192 & 3.75 & 0.40 \\
\hline
\end{tabular}

Tablo 2'de öğretmenlerin örgütsel muhalefet algılarına ait ortalamanın 2.64 olduğu ve bu değerin orta düzeye karş1lık geldiği, örgütsel yalnızlık algılarına ait ortalamanın ise 3.49 olduğu; bu değerin de yüksek düzeye karşılık geldiği görülmektedir.

\section{Öğretmenlerin Örgütsel Muhalefet ve Örgütsel Yalnızlık Algılarının Çeşitli Değiş̧kenlere Göre İncelenmesine Yönelik Bulgular}

Öğretmenlerin örgütsel muhalefet ve örgütsel yalnızlık algılarının cinsiyet, mezuniyet durumu ve mezun olunan fakülte değişkenlerine göre istatistiksel olarak anlamlı bir biçimde farklılık gösterip göstermediğini test etmek için öncelikle varaynsların homojen olup olmadığ 1 test edilmiş ve varyansların cinsiyet değişkeni için homojen olduğunun (Levene=.021; $\mathrm{p}=.899$ ), mezuniyet durumu değişkeni için homojen olduğu (Levene=.031; p=.782), mezun olunan fakülte değişkeni için de homojen olduğu (Levene $=.039 ; \mathrm{p}=.859$ ) belirlenmesi üzerine t-Testi yapılmış olup, Tablo 3 'te elde edilmiş olan bulgulara yer verilmiştir.

Tablo 3

Öğretmenlerin Örgütsel Muhalefet ve Örgütsel Yalnızlık Algılarının Cinsiyet, Mezuniyet Durumu, Mezun Olunan Fakülte Değişkenlerine Göre t-Testi Bulguları

\begin{tabular}{|c|c|c|c|c|c|c|c|c|}
\hline Ölçek & Değişken & & $\mathbf{n}$ & $\overline{\mathbf{X}}$ & $\mathbf{S}$ & $\mathbf{t}$ & sd & p \\
\hline \multirow{6}{*}{$\begin{array}{l}\text { Örgütsel } \\
\text { Muhalefet }\end{array}$} & \multirow{2}{*}{ Cinsiyet } & Kadın & 116 & 2.61 & 0.88 & \multirow{2}{*}{-.87} & 190 & \multirow[t]{2}{*}{0.43} \\
\hline & & Erkek & 76 & 2.68 & 0.84 & & & \\
\hline & Mezuniyet & Lisans & 166 & 2.88 & 0.97 & \multirow{2}{*}{-1.91} & 190 & \multirow[t]{2}{*}{$0.02 *$} \\
\hline & Durumu & Lisansüstü & 26 & 2.61 & 0.83 & & & \\
\hline & Mezun Olunan & Eğitim & 163 & 2.65 & 0.87 & \multirow{2}{*}{.81} & 190 & \multirow[t]{2}{*}{0.45} \\
\hline & Fakülte & Diğer & 29 & 2.47 & 0.82 & & & \\
\hline \multirow{6}{*}{$\begin{array}{l}\text { Örgütsel } \\
\text { Yalnızlık }\end{array}$} & \multirow{2}{*}{ Cinsiyet } & Kadın & 116 & 3.60 & 0.69 & \multirow{2}{*}{.66} & 190 & \multirow[t]{2}{*}{0.67} \\
\hline & & Erkek & 76 & 3.47 & 0.72 & & & \\
\hline & Mezuniyet & Lisans & 166 & 3.75 & 0.66 & \multirow{2}{*}{-1.95} & 190 & \multirow[t]{2}{*}{0.15} \\
\hline & Durumu & Lisansüstü & 26 & 3.47 & 0.70 & & & \\
\hline & Mezun Olunan & Eğitim & 163 & 3.49 & 0.72 & \multirow[b]{2}{*}{.30} & 190 & \multirow[t]{2}{*}{0.91} \\
\hline & Fakülte & Diğer & 29 & 3.60 & 0.61 & & & \\
\hline
\end{tabular}

$* \mathrm{p}<.05$

Tablo 3 incelendiğinde öğretmenlerin örgütsel muhalefet algıları öğretmenlerin cinsiyetlerine ve mezun oldukları fakülte değişkenlerine göre farklılık göstermezken $(\mathrm{p}>.05)$, mezuniyet durumu değişkenine göre anlamlı farkl1lı göstermektedir $(\mathrm{t}=-1,91 ; \mathrm{p}=0,02<.05)$. Buna göre lisansüstü mezunu öğretmenlerin örgütsel muhalefet algıları $(\overline{\mathrm{X}}=2,61)$, lisans mezunu öğretmenlere $(\overline{\mathrm{X}}=2,88)$ göre daha düşük düzeydedir. Ayrıca öğretmenlerin örgütsel yalnızlık algıları cinsiyet, mezuniyet durumu ve mezun olunan fakülte değişkenlerine göre istatistiksel olarak anlamlı farklılık göstermediği (p> .05) bulgusuna ulaşılmıştır.

Öğretmenlerin örgütsel muhalefet algılarının yaş, branş ve mesleki kıdem değişkenlerine göre anlamlı farklılık gösterip göstermediğini test etmek için öncelikle varaynsların homojen olup olmadığı test edilmiş ve varyansların yaş değişkeni için homojen olduğunun (Levene $=.036 ; \mathrm{p}=.785$ ), branş 
değişkeni için homojen olduğu (Levene $=.042 ; \mathrm{p}=.819)$, kıdem değişkeni için de homojen olduğu (Levene $=.041 ; \mathrm{p}=.753$ ) belirlenmesi üzerine ANOVA testi yapılmış olup Tablo 4 'te elde edilmiş olan bulgulara yer verilmiştir.

Tablo 4

Öğretmenlerin Örgütsel Muhalefet Algılarının Yaş, Branş ve Mesleki Kıdem Değişkenlerine Göre ANOVA Bulgularl

\begin{tabular}{|c|c|c|c|c|c|c|c|c|c|c|c|}
\hline Değişken & & n & $\overline{\mathbf{X}}$ & $\mathbf{S}$ & V.K. & K.T. & sd & K.O. & $\mathbf{F}$ & $\mathbf{p}$ & Fark \\
\hline \multirow{4}{*}{ Yaş } & 30 ve alt1 (1) & 100 & 2.43 & 0.84 & G.Aras1 & 5.23 & 3 & 1.81 & \multirow{4}{*}{2.93} & \multirow{4}{*}{0.02} & \multirow{4}{*}{$1-2$} \\
\hline & $31-40(2)$ & 60 & 2.78 & 0.88 & Grup içi & 221.81 & 188 & 0.68 & & & \\
\hline & $41-50(3)$ & 15 & 2.71 & 0.76 & Toplam & 226.95 & & & & & \\
\hline & $51 \mathrm{ve}+(4)$ & 17 & 2.70 & 0.98 & & & & & & & \\
\hline \multirow{3}{*}{ Branş } & Okul Öncesi (1) & 33 & 2.81 & 0.81 & G.Aras1 & 2.35 & 3 & 1.22 & \multirow{3}{*}{1.91} & \multirow{3}{*}{0.24} & \multirow{3}{*}{ - } \\
\hline & Sinif (2) & 47 & 2.49 & 0.92 & Grup içi & 223.68 & 188 & 0.68 & & & \\
\hline & Branş (3) & 112 & 2.61 & 0.85 & Toplam & 226.95 & & & & & \\
\hline \multirow{4}{*}{ Kidem } & $0-5$ yil (1) & 87 & 2.45 & 0.85 & G.Aras1 & 4.97 & 3 & 1.72 & \multirow{4}{*}{2.88} & \multirow{4}{*}{0.02} & \multirow{4}{*}{$1-3$} \\
\hline & 6-10 y1l (2) & 61 & 2.71 & 0.84 & Grup içi & 221.96 & 188 & 0.68 & & & \\
\hline & $11-19$ yll (3) & 27 & 2.85 & 0.97 & Toplam & 226.95 & & & & & \\
\hline & 20 yil ve $+(4)$ & 17 & 2.60 & 0.77 & & & & & & & \\
\hline
\end{tabular}

Öğretmenlerin örgütsel muhalefet algıları branşa göre anlamlı farkl11ık göstermezken ( $\mathrm{F}=1.91$; $\mathrm{p}=0,24>.05)$, yaş $(\mathrm{F}=2,93 ; \mathrm{p}=0,02<.05)$ ve mesleki kıdem $(\mathrm{F}=2,88 ; \mathrm{p}=0,02<.05)$ değişkenlerine göre anlamlı farklılık göstermiştir. Buna göre, 31-40 yaş aralığındaki öğretmenlerin örgütsel muhalefet algıları, 30 yaş ve altındaki yaş aralığındaki öğretmenlere göre daha yüksektir. 11-19 yıl kıdeme sahip öğretmenlerin örgütsel muhalefet algıları da 0-5 yıl kıdeme sahip öğretmenlere göre daha yüksektir.

Öğretmenlerin örgütsel yalnızlık algılarının yaş, branş ve mesleki kıdem değişkenlerine göre anlamlı farklılık gösterip göstermediğini test etmek için öncelikle varaynsların homojen olup olmadığı test edilmiş ve varyansların yaş değişkeni için homojen olduğunun (Levene $=.044 ; p=.764$ ), branş değişkeni için homojen olduğu (Levene=.047; p=.799), kıdem değişkeni için de homojen olduğu (Levene $=.039 ; \mathrm{p}=.811$ ) belirlenmesi üzerine ANOVA testi yapılmış olup Tablo 5'te elde edilmiş olan bulgulara yer verilmiştir.

Tablo 5

Öğretmenlerin Örgütsel Yalnızlık Algılarının Yaş, Branş ve Mesleki Kıdem Değişkenlerine Göre ANOVA Bulgulart

\begin{tabular}{|c|c|c|c|c|c|c|c|c|c|c|}
\hline Değișken & & $\mathbf{N}$ & $\overline{\mathbf{X}}$ & $\mathbf{S}$ & V.K. & K.T. & sd & K.O. & $\mathbf{F}$ & p \\
\hline \multirow{4}{*}{ Yaş } & 30 ve alt1 (1) & 100 & 3.43 & 0.69 & G.Aras1 & 1.72 & 3 & 0.64 & 1.48 & 0.31 \\
\hline & $31-40(2)$ & 60 & 3.68 & 0.75 & Grup içi & 139.17 & 188 & 0.36 & & \\
\hline & $41-50(3)$ & 15 & 3.63 & 0.45 & Toplam & 140.80 & & & & \\
\hline & $51 \mathrm{ve}+(4)$ & 17 & 3.48 & 0.71 & & & & & & \\
\hline \multirow{3}{*}{ Branş } & Okul Öncesi (1) & 33 & 3.49 & 0.68 & G.Aras1 & 0.37 & 3 & 0.28 & 0.60 & 0.70 \\
\hline & Sinif (2) & 47 & 3.45 & 0.78 & Grup içi & 140.33 & 188 & 0.36 & & \\
\hline & Branş (3) & 112 & 3.61 & 0.67 & Toplam & 140.80 & & & & \\
\hline \multirow{4}{*}{ Kidem } & $0-5$ y1l (1) & 87 & 3.46 & 0.69 & G.Aras1 & .93 & 3 & 0.31 & 0.95 & 0.46 \\
\hline & $6-10$ y1l (2) & 61 & 3.60 & 0.68 & Grup içi & 139.87 & 188 & 0.36 & & \\
\hline & $11-19$ y1l (3) & 27 & 3.70 & 0.81 & Toplam & 140.80 & & & & \\
\hline & $20 \mathrm{y} 1 \mathrm{lve}+(4)$ & 17 & 3.45 & 0.63 & & & & & & \\
\hline
\end{tabular}

$* \mathrm{p}<.05$

Tablo 5 incelendiğinde, öğretmenlerin örgütsel yalnızlık algılarının yaş $(\mathrm{F}=1.48 ; \mathrm{p}=0,31>.05)$, branş $(\mathrm{F}=0.60 ; \mathrm{p}=0,70>.05)$, ve mesleki kıdem $(\mathrm{F}=0.95 ; \mathrm{p}=0,46>.05)$, değişkenlerine göre istatistiksel olarak anlamlı bir biçimde farklılık göstermediği görülmüştür.

Öğretmenlerin örgütsel muhalefet algılarının ile örgütsel yalnızlık algılarını yordama derecesini ortaya çıkarmak amacıyla regresyon yapılarak bulgular Tablo 6' da gösterilmiştir. 
Tablo 6

Öğretmenlerin Örgütsel Muhalefet Algılarının Örgütsel Yalnızlık Algılarını Yordama Gücüne İlişkin Regresyon Testi Bulgulari

\begin{tabular}{llllllll}
\hline Yordayıcı Değişken & B & Sh B & $\boldsymbol{\beta}$ & $\mathbf{T}$ & $\mathbf{p}$ & İkili r & Kısmi r \\
\hline Sabit & 1.33 & .34 & & 3.56 & $.00^{*}$ & & \\
Dikey Muhalefet & .29 & .01 & .26 & 5.74 & $.00^{*}$ & .36 & .24 \\
Yatay Muhalefet & .01 & .03 & .01 & .31 & $.00^{*}$ & .03 & .01 \\
Duygusal Yoksunluk & .03 & .04 & .03 & .73 & $.00^{*}$ & .07 & .03 \\
Sosyal Arkadaşlık & .27 & .02 & .18 & 4.66 & $.00 *$ & .39 & .29 \\
$\mathrm{R}=.408$ & $\mathrm{R}^{2}=.28$ & & & & & & \\
$\mathrm{~F}=18.67$ & $* \mathrm{p}=.01$ & & & & & & \\
\hline
\end{tabular}

Tablo 6'da görüldüğ̈ üzere örgütsel muhalefet ve örgütsel muhalefetin tüm alt boyutları örgütsel yalnızlığın ve örgütsel yalnızlığın tüm alt boyutlarının istatistiksel olarak anlamlı bir biçimde yordayıcısı olduğu tespit edilmiştir $\left(\mathrm{R}=.408 ; \mathrm{R}^{2}=.28 ; \mathrm{p}<.05\right)$. Bulgulara göre öğretmenlerin örgütsel muhalefet algıları örgütsel yalnızlık algılarının \%28'ini açıklamaktadır. Regresyon katsayılarının anlamlılığına ilişkin t-testi sonuçlan değerlendirildiğinde örgütsel muhalefet değiş̧keninin örgütsel yalnızlık üzerinde anlamlı (önemli) bir yordayıcı olduğu görülmektedir.

\section{Sonuç, Tartışma ve Öneriler}

Örgütler mevcut hedeflerine ulaşmak ve iyi ürün ortaya koymak için nitelikli ve iyi performans sergileyen işgörenlere ihtiyaç duyarlar. İyi performans da, kariyer, ekonomik katk1 ve terfi gibi diğer imkânları sağladığı için işgörenler tarafından değerli görülen bir durumdur. Bu amaçla örgüt ile işgörenler arasındaki bu beklentilerin karşılanması karşılıklı uyum ile mümkün olabilir. Bu durum her zaman böyle gerçekleşmeyebilir. Bazı zamanlarda örgüt içindeki bu uyumun bozulması işgörenlerin örgütlerine yönelik muhalif davranışlar sergilemelerine sebep olabilir.

Örgütsel muhalefet, temelde fikir ayrılığını ifade eden bir kavramdır. Çatışmaların veya farklı görüşleri içerse de, muhalefet eylemi önemli bir örgütsel iletişim davranışıdır. Bu bakımdan yöneticilerin örgütte olup bitenler hakkında bilgi edinebilecekleri veya alınan kararların sonuçlarıyla ilgili geri bildirim alabilecekleri bir işlevi vardır (Yıldırım, 2020). Bunların yanı sıra örgütsel muhalefetin yaşanması, örgütlerde çatışma ortamının oluşmasına, yabancılaşmaya, bireyselleşmeye, şiddet davranışlarının sergilenmesine ve örgütten ayrılmaya neden olabilir. Yaşanan muhalefetin önemsenmemesi ise, otokratik yapılı bir örgütün oluşması sonucunu ortaya çıkarabilir (Shahinpoor ve Matt, 2007).

$\mathrm{Bu}$ araştırmada uzaktan eğitim sürecindeki öğretmenlerin örgütsel muhalefet davranışları ile iş yaşamındaki yalnızlık duyguları arasındaki ilişkisi incelenmiştir. Bulgularda öğretmenlerin örgütsel muhalefet davranışları algı düzeyinin orta düzeyde olduğu görülmüştür. Bu bulguya göre öğretmenlerin okul içindeki genel muhalif davranışlarının fazla olmadığı söylenebilir. Uzaktan eğitim sürecinin yaşandığı dönemde öğretmenlerin genellikle okul içinde çok fazla bir arada bulunmamış olmaları, onların muhalif davranışları daha az sayıda göstermelerinde etkili olduğunu düşündürmektedir. Örgütsel muhalefet davranışı öğretmenlerin okul içinde kolektif olarak sergiledikleri bir davranış olarak düşünülebilir. Düşük muhalefetin olması da, bu süreçte evlerinden eğitim ve öğretimi sürdüren öğretmenler için olağan bir durum olarak görülebilir. Alanyazında bu araştırma bulgularını destekleyen benzer araştırmalar da bulunmaktadır (Garner, 2009; Kassing, 2008; Kassing ve Avtgis, 2009; Özdemir, 2010). Araştırmanın diğer bir değişkeni öğretmenlerin okuldaki yalnızlık algı düzeyinin tespit edilmesine yöneliktir. Bu bağlamda uzaktan eğitim sürecindeki öğretmenlerin iş yeri yalnızlığı algı düzeyinin ise yüksek düzeyde olduğu tespit edilmiştir. Araştırma bulgularına göre uzaktan eğitimin devam ettiği sürede öğretmenlerin muhalif davranışlardan geri durdukları fakat bu süreçte kendilerini yalnız hissettikleri söylenebilir. Bunun nedeninin bu süreçteki öğretmenlerin okul yöneticileri, meslektaşları ve öğrencileriyle yüz yüze etkileşim kuramadıklarından kaynaklandığı düşünülebilir. Bu çaşılma bulgularının aksine öğretmenlerin iş yaşamında yalnızlık 
düzeyinin düşük olduğu (Demirtaş ve Haşit, 2016; Gafa ve Dikmenli, 2019; Oğuz ve Kalkan, 2014; Sezen, 2014; Tabak ve Argon, 2018) bazıaraştırmalarda görülmüştür.

Araştırmaya katılan erkek ve kadın öğretmenlerin örgütsel muhalefet davranışlarının benzer olduğu, bunun yanında öğrenim durumlarına göre ise farklılık gösterdiği görülmüştür. Araştırmaya katılan ve lisansüstü mezunu öğretmenlerin örgütsel muhalefet davranışı algı düzeyi lisans mezunu öğretmenlere göre daha düşüktür. Bu durum, lisansüstü mezunu öğretmenlerin örgütsel faaliyetlere bakış açılarının farklı olduğunu düşündürmektedir. Uzaktan eğitim sürecindeki araştırmaya katılan öğretmenlerin yalnızlık algılarının ise cinsiyet, mezuniyet durumu ve mezun olunan fakülte düzeyine göre değişmediği görülmüştür. Literatürde erkek ve kadın öğretmenlerin iş yaşamındaki yalnızlık algı düzeyinin benzer olduğu bazı araştırmalar da vardır (Mercan, Oyur, Alamur, Gül ve Bengül, 2012; Oğuz ve Kalkan, 2014; Sezen, 2014; Yanık, 2012). Bunun aksine erkek ve kadın öğretmenlerin iş yaşamındaki yalnızlık algılarının farklı düzeyde olduğu (Demirtaş ve Haşit, 2016; Nartgün ve Demirer, 2012) araştırmalar da mevcuttur.

Araştırmada öğretmenlerin örgütsel muhalefet davranışları algı düzeyinin branşlarına göre benzer olduğu fakat yaş ve mesleki kıdemlerine göre farklılık gösterdiği görülmüştür. Buna göre, araştırmaya katılan otuz yaş ve üzeri ile mesleki deneyimi on yılın üzerinde olan öğretmenlerin, örgütsel muhalefet etme davranışlarının daha yüksek olduğu anlaşılmıştır. Bu bulguya göre, yaş olarak daha ileri yaş vemesleki kıdeme sahip öğretmenlerin muhalif davranışları daha çok sergiledikleri söylenebilir. Benzer şekilde, Miceli (2004) tarafından yapılan araştırmada örgütsel muhalefetin mesleki kıdeme göre anlamlı farklılık gösterdiği, ancak Özdemir (2010) ve Sims ve Keenan (1998) tarafından yapılan araştırmalarda da örgütsel muhalefet davranışı yaş ve mesleki kıdeme göre farklılık göstermediği ortaya çıkmıştır. Bu araştırmada da yaşı ve kıdemi fazla olan öğretmenlerin örgütsel muhalif davranışlarını daha fazla sergiledikleri tespit edilmiştir. Bu durum, genç olan öğretmenlerin örgütsel değişimi ve yenilikleri daha çabuk kabul etmelerine rağmen yaşı ve mesleki kıdemi artan öğretmenlerin bu süreçleri daha zor kabul ettiklerini ve muhalif davranışlar sergilediklerini düşündürmektedir. Öğretmenlerin iş yaşamındaki yalnızlık algılarının yaş, branş ve mesleki kıdemleri açısından benzer olduğu literatürdeki bazı araştırmalarla örtüşmektedir (Demirtaş ve Haşit, 2016; Oğuz ve Kalkan, 2014; Sezen, 2014). Ayrıca, Gafa ve Dikmeli (2019) öğretmenlerin mesleki çalışma sürelerinin iş yaşamındaki yalnızlık algıları arasında fark yaratmadığını ifade etmişlerdir. Bunun yanı sıra Oğuz ve Kalkan (2014), mesleki kıdemleri ile iş yaşamındaki yalnızlık algılarının farklılaştığını belirtmişlerdir. Bulgularında on yıl üzerindeki mesleki çalışma süresine sahip öğretmenlerin iş yaşamında kendilerini daha yalnız düşündüklerini ifade etmişlerdir. Bir başka araştırmada geçici sözleşmeli çalışanların, sürekli sözleşmeli çalışanlara göre işyerinde daha fazla yalnızlık yaşadıkları görülmüştür (Moens, Baert, Verhofstadt ve Van Ootegem, 2021).

Araştırmanın önemli bir bulgusu da, uzaktan eğitim sürecindeki öğretmenlerin örgütsel muhalefet davranışları ile iş yaşamındaki yalnızlık algıları arasındaki ilişkiye yöneliktir. Buna göre, öğretmenlerin örgütsel muhalefet etme davranışları ile yalnızlık duyguları arasında orta düzey bir ilişki görülmüştür. Bu araştırmada araştırmaya katılan uzaktan eğitim sürecindeki öğretmenlerin muhalif davranışlarıyla yalnızlık yaşamaları arasında orta düzeyde ilişki görülmüştür. Ayrıca örgütsel muhalefetin iş yaşamındaki yalnızlık duygularının anlamlı bir yordayıcısı olduğu tespit edilmiştir. Buna göre, öğretmenlerin örgütsel muhalif davranışlarının yalnızlık algılarını etkilediği söylenebilir. Araştırmada elde edilen bu bulgu, uzaktan eğitim sürecindeki öğretmenlerin muhalif davranışlarıyla iş yaşamındaki yalnızlık duyguları arasında ilişi olduğunu göstermektedir. Buna karşın korku hissetme ve topluluk olma eksikliği gibi bazı çevresel faktörlerin işle ilgili yalnızlık duygularında rol oynadığı görülmüştür. $\mathrm{Bu}$ bulguda öğretmenlerin topluluk içinde olmadıklarında ve çevreden korku hissettiklerinde yalnızlık duygularının arttığı ifade edilmektedir. Ayrıca olumsuz bir duygusal iklimin ve meslektaş desteği eksikliğinin çalışanlarda yalnızlık duygusunu olumsuz etkilediği literatürdegörülmüştür. Bunun yanında işyerinde kişilerarası sorunları çözmek için girişimlerde bulunma ve bir organizasyon içindeki psikolojik çalışma ortamını iyileştirmenin, çalışanların sosyal ve duygusal yalnızlığını azalttığı görülmüştür (Wright, 2005). Uzaktan eğitimde öğretmenlerin yalnızlık algısının yüksek olması olağan dışı çalışma şartlarından kaynaklı bir durum olarak görülebilir. Olağan şartlarda karş1lıklı saygı, nezaket ve hoşgörünün yaygın olduğu eğitim örgütlerinde, meslektaş desteği 
ile öğretmenlerin sosyal ve duygusal yalnızlık yaşamalarının daha az olması beklenebilir. $\mathrm{Bu}$ bağlamda araştırmanın farklı örneklemlerde irdelenmesi ve öğretmenlerin muhalif davranışları ile yalnızlık duygularının sebeplerinin daha iyi anlaşılması için nitel araştırmaların yapılması önerilebilir.

\section{Araştırmacıların Katkı Oranı}

Araştırmanın her aşamasında yazarların eşit katkısı bulunmaktadır.

\section{Çıkar Çatışması}

Araştırmada herhangi bir çıkar çatışması bulunmamaktadır.

\section{Kaynaklar}

Ardoğan, R. (2004). Teorik temeller ve tarihsel gerilimler arasında İslam kültüründe siyasal muhalefet. Cumhuriyet Üniversitesi İlahiyat Fakültesi Dergisi, 8(2), 171-189.

Büyüköztürk, Ş., Çakmak, E., Akgün, Ö. E., Karadeniz, Ş. ve Demirel, F. (2008). Bilimsel araştırma yöntemleri (Geliştirilmiş 2. baskı). Ankara: Pegem A Yayıncılık.

Dağl1, A. (2015). Örgütsel muhalefet ölçeğinin Türkçeye uyarlanmas1: Geçerlik ve güvenirlik çalışmaları. Elektronik Sosyal Bilimler Dergisi, 14(53), 198 218.https://doi.org/10.17755/esosder.45359

Demirbaş, B. ve Haşit, G. (2016). İş yerinde yalnızlık ve işten ayrılma niyetine etkisi: Akademisyenler üzerine bir uygulama. Anadolu Üniversitesi Sosyal Bilimler Dergisi, 16(1), 137-158.

Doğan, T., Çetin, B. ve Sungur, M. Z. (2009). İş yaşamında yalnızlık ölçeği Türkçe formunun geçerlilik ve güvenilirlik çalışması. Anadolu Psikiyatri Dergisi, 10(6), 271-277.

Gafa, İ. ve Dikmenli, Y. (2019). Sınıf öğretmenlerinin iş doyumu ve iş yaşamındaki yalnızlık düzeylerinin incelenmesi. Ahi Evran Üniversitesi Sosyal Bilimler Enstitüsü Dergisi, 5(1), 131150. https://doi.org/10.31592/aeusbed.567562

Garner, J. T. (2009). Strategic dissent: Expressions of organizational dissent motivated by influence goals. International Journal of Strategic Communication, 3(1), 3451.https://doi.org/10.1080/15531180802606471

Güney, S. (2004). Yönetim organizasyon ve örgütsel davranış terimler sözlüğ̈̈ (1. Bask1). Ankara: Siyasal Yayınevi.

Kaplan, S. (2011). Öğretmenlerin is yerinde yalnızlı duygularının okullardaki örgütsel güven düzeyi ve bazı değişkenler açısından incelenmesi. Yüksek Lisans Tezi, Selçuk Üniversitesi Sosyal Bilimler Enstitüsü, Konya.

Karaduman, M. (2013). Iş̧ yaşamında yalnızlık algısının örgütsel vatandaşlık davranışı ile ilişkisi ve ögretmenler üzerinde bir uygulama. Yüksek Lisans Tezi, Uludağ Üniversitesi, Sosyal Bilimler Enstitüsü, Bursa.

Karasar, N. (2010). Bilimsel araştırma yöntemi. Ankara: Nobel Yayınevi.

Kassing, J. W. (2007). Articulating, antagonizing, and displacing: A model of employee dissent. Communication Studies, 48(1),311-332.https://doi.org/10.1080/10510979709368510 
Kassing, J. W. (2008). Development and validation of the organizational dissentscale. Management Communication Quarterly, 12(2), 183-229.https://doi.org/10.1177/0893318998122002

Kassing, J. W. (2008). Considerthis: A comparison of factors contributing to employees' expressions of dissent. Communication Quarterly, 57(3), 342355.https://doi.org/10.1080/01463370802240825

Kassing, J. W. and Armstrong, T. A. (2002). Someone's going to hear about this: Examining the association between dissent-triggeringeventsandemployees' dissent expression. Management Communication Quarterly, 16(1), 39-65.https://doi.org/10.1177/0893318902161002

Kassing, J. W. and Avtgis, T. A. (2009). Examining the relation ship between organizational dissentan daggressive communication. Management Communication Quarterly, 13(1), 100115.https://doi.org/10.1177/0893318999131004

Kayaalp, E. ve Özdemir, T. Y. (2019). Öğretmenlerin örgütsel sessizlik, örgütsel yalnızlık ve örgütsel yabancılaşma algılarının örgütsel sinizm düzeyleriyle ilişkisi. Dicle Üniversitesi Ziya Gökalp Ĕ̈itim Fakültesi Dergisi, 1(38), 101-113.

Malhotra, N. K. (2004). Marketing research and applied orientation (4. Edition). Australia: Pearson Prentice Hall.

Mercan, N., Oyur, E., Alamur, B., Gül, S. ve Bengül, S. (2012). İşyeri yalnızlığı ve sosyal fobi arasındaki ilişkiye yönelik bir araştırma. Organizasyon ve Yönetim Bilimleri Dergisi, 4(1), 213-226.

Miceli, M. P. (2004). Whistle-blowing research and the insider: Lessons learned and yet to be learned. Journal of Management Inquiry, 4, 364-366.https://doi.org/10.1177/1056492604270801

Moens, E., Baert, S., Verhofstadt, E. and Van Ootegem, L. (2021). Does loneliness lurk in tempwork? Exploring the associations between temporary employment, loneliness at work and jobsatisfaction. PloSone, 16(5), 2-9.https://doi.org/10.1371/journal.pone.0250664

Nartgün, Ş. S. ve Demirer, S. (2012).Öğretmenlerin örgütsel sessizlik ile iş yaşamında yalnızlık düzeylerine ilişkin görüşleri. Bayburt Eğitim Fakültesi Dergisi, 7(2), 139-157.

Oğuz, E. ve Kalkan, M. (2014). Öğretmenlerin iş yaşamında algıladıkları yalnızlık ile sosyal destek düzeyleri arasındaki ilişki. Illköğretim Online, 13(3), 787-795.

Özdemir, M. (2010). Ankara ili kamu liselerinde görev yapan yönetici ve öğretmenlerin örgütsel muhalefete ilişkin görüşleri. Doktora Tezi, Ankara Üniversitesi, Eğitim Bilimleri Enstitüsü, Ankara.

Özdemir, M. (2011). Lise yöneticilerinin öğretmenlerin örgütsel muhalefet davranışlarına ilişkin görüşleri. Kuram ve Uygulamada Eğitim Bilimleri, 4, 1895-1908.

Redding, W. C. (1985). Rocking boats, blowing whistles, and teaching speech communication. Communication Education, 34(3), 245-258.https://doi.org/10.1080/03634528509378613

Sergin, C. and Kinley, T. (2005). Social skills deficiets among the social anxious: Reflections from other and loneliness. Motivation and Emotion, 29(1), 124.https://doi.org/10.1007/BF02260670

Sezen, G. (2014). Öğretmenlerin işle bütünleşme ve iş yaşamında yalnızlık düzeyleri arasındaki ilişkinin incelenmesi. Yüksek Lisans Tezi, Sakarya Üniversitesi, Eğitim Bilimleri Enstitüsü, Sakarya. 
Shahinpoor, N. and Matt, B. F. (2007). The power of one: Dissent and organizational life. Journal of Business Ethics, 74(1), 37-48.https://doi.org/10.1007/s10551-006-9218-y

Sims, R. L. and Keenan, J. P. (1998). Predictors of external whistleblowing: Organizational and intrapersonal variables. Journal of Business Ethics, 17, 411-421.

Şahin, A. ve Atbaşı, Z. (2020). Olumlu okul iklimi oluşturmada öğretmenin rolünün incelenmesi. Ahi Evran Üniversitesi Sosyal Bilimler Enstitüsü Dergisi, 6(3), 672689.https://doi.org/10.31592/aeusbed.742972

Tabak, I. ve Argon, T. (2018). Duygusal işçilik ve iş yaşamında yalnızlığa yönelik öğretmen görüşleri. İnönü Üniversitesi Ë̆itim Fakültesi Dergisi, 19(3), 1-13. https://doi.org/10.17679/inuefd.351583

Türk Dil Kurumu (2021).Türkçe sözlük.http://www.tdk.gov.tr adresinden 15/08/2021 tarihinde erişilmiştir.

Wright, S. L, Burt, C. D. and Strongman, K. T. (2006). Loneliness in theworkplace: Construct definition and scale development. New Zealand Journal of Psychology, 35(2), 59-68.

Wright, S. L. (2005). Loneliness in the workplace. Doctoral Dissertation, University of Canterbury, New Zealand.

Yakut, S., ve Certel, H. (2016). Öğretmenlerde yalnızlık düzeyinin çeşitli değişkenler açısından incelenmesi. Birey ve Toplum, 6(11), 169-193.

Yanık, C. (2012). Örgütsel sessizlik ile güven arasındaki ilişki ve eğitim örgütlerinde bir araştırma. Yüksek Lisans Tezi, Yeditepe Üniversitesi, Sosyal Bilimler Enstitüsü, İstanbul.

Yıldırım, A. (2020). Örgütsel adalet algısının örgütsel muhalefet davranışına etkisi: eğitim çalışanları üzerine bir araştırma. Süleyman Demirel Üniversitesi Iktisadi ve İdari Bilimler Fakültesi Dergisi, 25(2), 203-219.

Zikmund, W. G. (2007). Business research methods (5. Ed.). New York: The Dryden Press. 


\section{Extended Abstract}

\section{Introduction}

The aim of this research is to examine the organizational dissent and organizational loneliness perception levels of teachers in the distance education process. This aim will be examined in the context of the following questions:

1. What are the teachers' perceptions of organizational dissent and organizational loneliness?

2. Do teachers' perceptions of organizational dissent and organizational loneliness differ significantly according to gender, faculty graduated, education level, branch, age and professional seniority?

3. Is there a relationship between teachers' perceptions of organizational dissent and organizational loneliness?

4. Are teachers' perceptions of organizational dissent a significant predictor of organizational loneliness?

With the implementation of the distance education process, it is important to examine the organizational dissent and organizational loneliness perception levels of the teachers who try to manage this process well. In the literature review, no study was found that examines the relationship between teachers' organizational dissent and organizational dissent perception levels in educational organizations. This situation reveals the originality of the study.

It is possible to say that teachers, who have important duties in educational organizations, need more belonging and love, unlike the employees of other organizations, and that they meet this need from the environment they are in (Nartgün and Demirer, 2012). In addition to the expectations of teachers from their environment, the expectations of other stakeholders from teachers draw attention as a major stress factor. It is possible for teachers to show dissent or to encounter a feeling of loneliness after the stress experienced. According to Karaduman (2013), experienced negative emotions will reduce teachers' motivation, negatively affect their job satisfaction and weaken their communication with other stakeholders.

Organizational dissent involves the employees of the organization having conflicts with the employees or managers against the practices they encounter in the organization, and showing the emerging problems with different behaviors (Redding, 1985). The behaviors exhibited by the employees emerge based on the behaviors encountered in the organization, the current situation and the events experienced (Kassing and Armstrong, 2002).

Organizational loneliness is a situation that arises in business life, unlike the loneliness in the individual's private life, and is experienced as a result of poor relationships and difficulty in establishing friendships (Kayaalp and Özdemir, 2020). The weakening of relations with other employees in the organization and the loss of time spent together as a result of the loss of confidence cause organizational loneliness (Mercan, Oyur, Alamur, Gül and Bengül, 2012).

\section{Method}

In this study, the survey model, which is one of the quantitative research designs, was used on teachers' organizational dissent and organizational loneliness perception levels. The relationship between teachers' organizational dissent and organizational loneliness perception levels was determined in the relational survey model. The population of the research consists of 13422 teachers working in Sakarya in the 2020-2021 academic year. The sample was created by using convenience sampling method, which is one of the non-random sampling methods. In this context, the sample of the research consists of 192 teachers. Organizational Dissent Scale and Loneliness at Work Scale were used to collect data. Descriptive statistics were made on the collected data. Prior to the collection of 
research data, ethics committee approval was obtained with the decision of İnönü University Social and Human Sciences Scientific Research Ethics Committee dated 05/07/2021 and numbered E.61621. After the decision that the research was ethically appropriate, the research process was started.

\section{Findings}

It can be stated that this value, where the average of teachers' perceptions of organizational dissent is 2.64 , corresponds to a low level, while the average of their perception of organizational loneliness is 3.49 , which corresponds to a high level. While teachers' perceptions of organizational dissent do not differ significantly according to gender and graduated faculty variables, they differ significantly according to the graduation status variable. While teachers' perceptions of organizational dissent did not differ significantly according to the branch, it was determined that there was a significant difference according to the variables of age and professional seniority. According to age, the perception of organizational dissent of teachers aged 31-40 is higher than teachers aged 30 and below. According to professional seniority, teachers with 11-19 years of seniority have higher perceptions of organizational dissent than teachers with 0-5 years of seniority.It was determined that teachers' perceptions of organizational loneliness did not differ significantly according to age, branch and professional seniority variables.According to the correlation analysis results, it was determined that there was a positive and moderate relationship between teachers' perceptions of organizational dissent and organizational loneliness. Organizational dissent was found to be a significant predictor of organizational loneliness $(\mathrm{R}=.408 ; \mathrm{R} 2=.28 ; \mathrm{p}<.01)$. According to the findings, teachers' perceptions of organizational dissent explain $28 \%$ of their organizational loneliness perceptions.

\section{Conclusion, Discussion and Recommendations}

According to the findings of the study, it can be said that while the distance education continues, the teachers hold back from their dissental behaviors and feel alone in this process. It can be thought that the reason for this is that the teachers in this process could not interact face-to-face with their school administrators, colleagues and students. The organizational opposition behavior perception levels of the teachers who participated in the research and who have a graduate degree are lower than the teachers with a graduate degree. It was observed that the loneliness perceptions of the teachers participating in the study in the distance education process did not change according to gender, graduation status and the level of the graduated faculty. This finding obtained in the study shows that there is a relationship between the dissental behaviors of teachers in the distance education process and their feelings of loneliness in business life. On the other hand, some environmental factors such as fear and lack of community have been found to play a role in feelings of work-related loneliness (Wright, 2005).

In the study, it was seen that the perception level of teachers' organizational dissent behaviors was similar according to their branches, but differed according to their age and professional seniority. Accordingly, it was understood that the teachers who participated in the study at the age of thirty and over and with more than ten years of professional experience had higher organizational dissent. According to this finding, it can be said that older and more senior teachers exhibit more oppositional behaviors. 